\title{
The lost potential of creative urban regeneration: Restructuring Ljubljana's former tobacco factory
}

In the transition that saw intense spatial and economic changes in Slovenia, urban creative activities were often regarded as an important development factor allowing the reurbanization and revitalization of several former industrial areas. These were generally relatively spontaneous unplanned processes to spatially and economically develop degraded areas where, following the bottom-up principle, various creative individuals and groups gradually revitalized these areas. This article analyses the role of creative activities in breathing life into degraded areas by looking at the development of soft (social) factors in the form of social networks. It highlights the problem of local authorities and state institutional actors' non-perception of, inappropriate approach to, or insufficient consideration of creative social networks in developing these spaces. Drawing on semi-structured interviews, the case of the former tobacco factory is presented as an example of the accumulation of social capital linked to social networks, within which the area's new economic and spatial restructuring is perceived to be an unnecessary element of the renovation.

Keywords: creative activities, social networks, degraded areas, tobacco factory 


\section{Introduction}

Soon after Slovenia gained its independence, urban policies related to developing the creative sector gained importance. The introduction of a market economy together with largescale systemic changes to spatial planning policies identified the creative sector as a key driver of spatial and economic development during the transition (Bole, 2008; Ravbar, 2011). Highlighting the creative sector as a vital promoter of spatial and economic development was not accidental (European Commission, 2010; Regionalna razvojna agencija ljubljanske urbane regije, 2007; Služba vlade Republike Slovenije za razvoj, 2008), but relied on relatively successful development models used in other economically developed countries (Internet 2; Ministry of Economy, Trade and Industry, 2012; Internet 1). In so doing, creative activities, often referred to as creative economies and creative industries, are expected to form a valuable tool for developing different industries and helping replace lost jobs in traditional industrial and service sectors (Howkins, 2001; Hesmondhalgh, 2002). While copying and trying to implement foreign models of creative urban regeneration policies in Slovenia, several development discrepancies and complications surfaced.

The transfer of urban policies from one environment to another is not simply a "mechanical process of replication", as Peck and Theodore (2015:25) found, but is also inextricably linked to "urban policy mutations" (Peck \& Theodore, 2015) that respond and adapt to specific local features. Although some development models of creative urban policies seem attractive and advanced at first glance, they cannot be transferred to a new socioeconomic context without the side effects of policy mutations (Peck, 2011). Clarke et al. (2015) believe the appropriate metaphor for any introduction of new policies should be "translation" and not "intact transfer" due to the intense dialogical, sometimes even conflicting, transformation processes, which are simply inseparable from attempts to introduce systemic innovations in local environments. Most critical analyses of "imported" creative urban policies do not criticize the use of the concept of creative urban regeneration or the creative city itself, but focus on the problematic use or nonselective application of these concepts in a particular environment. This article therefore does not focus on the usefulness of applying creative urban policies, but on the way they are applied and realized.

For various reasons (e.g., localism-related political relations, economic transformations, and unconsolidated institutional structures), unreflective uses of creative urban regeneration policies can historically be seen in the Slovenian context. Several strategic documents emerging in this period sought to partly address policies of creative urban regeneration (European Commission, 2010; Mestna občina Ljubljana, 2012, 2016, 2020; Regionalna razvojna agencija ljubljanske urbane regije, 2007, 2014, 2019; Internet 3). Nonetheless, due to disregard or misunderstanding of the special contextual features of "creative ecosystems" (Jeffcutt, 2004; Cohendet et al., 2010; Rivas, 2011) in Slovenian cities, spatial interventions were made that either reduced or completely overlooked, if not denied, certain forms of social creative potential and how they could contribute to the development of the socioeconomic system and quality of life in Slovenia.

This article focuses on the restructuring of the former tobacco factory in Ljubljana, which is a paradigmatic example of post-transition processes of urban change. This questionable transformation could be also described as the closure of spaces of temporary creative use without accounting for the value of soft, intangible, informal forms of creative potential held by the socioeconomic activities that accumulated in the area in the meantime. The former tobacco factory was a central area where creative activities for small businesses were concentrated in the Ljubljana region (Žaucer et al., 2012; Uršič, 2016; Kozina \& Bole, 2018), but much of the space was closed down or sold off to private investors in 2019, forcing the creatives to restructure, change their location, or shut down their activities. This article analyses and highlights the unreflective closure of an important part of one of the city's largest concentrations of creative activity. It emphasizes that the operation of a creative ecosystem like the tobacco factory area is based on "soft factors" (Murphy \& Redmont, 2008; Martin-Brelot et al., 2010) and the principles of "social networks" (Shaw et al., 2016; Boessen et al., 2018), which are insufficiently discussed in Slovenian political and strategic documents on the topic of creativity. It tests whether social networks in relation to creativity and location during the radical transformation of the area can be protected at all by simply physically relocating creative actors to other locations in the city or region. This article uses the term social network to refer to the spatio-social or community-based social networks and not digital social networks. The effects of restructuring the tobacco factory area on the creative ecosystem's operation are presented based on data in the longitudinal project Urban Education Live, which ran from 2017 to 2020. Special attention is paid to the overlooked influence of soft (social) factors in the formation, operation, and long-term development of the creative ecosystem of the city and the broader region. 


\section{Social networks and the development of urban creative activities from a long-term perspective}

Soft (social) factors are typically contextual elements that help improve aspects of social functioning in specific settings (Murphy \& Redmont, 2008; Martin-Brelot et al., 2010; Musterd \& Gritsai, 2013). Whereas hard (physical) factors mostly depend on the availability of specific resources, soft-location factors refer to improvement in the overall quality of life or personal lifestyles. This research includes social networks as part of soft attractive factors due to their functional role as a catalyst for social engagement or sociability in the study location. The problem of misunderstanding the impact of soft (social) elements on the creative ecosystem is actually a problem of the (non)development of the "milieu" (Meusburger, 2009) in which creative actors are involved. If the creative ecosystem can be defined as "an environment that supports creative activities through specialized ways of exchanging, interacting and communicating between people and their economic, social and cultural capital" (Rivas, 2011: 4), the creative milieu may be perceived as its key component that includes "a micro-social context that encompasses people and their relationship to the socio-cultural system, the environment and the local community" (Uršič \& Imai, 2020: 8). From this viewpoint, the creative milieu complements traditional components of the creative ecosystem such as creative classes, creative production, creative locations, and creative industries or economies (Pratt, 2004; Florida et al., 2006; Poljak-Istenič, 2017). It also integrates components of particular or local (contextually) related knowledge, which at first glance seems irrelevant, mundane, and separate from the sphere of creative economies. Stressing the importance of the creative milieu draws attention to the importance of the bottom-up process of establishing a creative system; namely, from local communities through creative individuals and groups to creative economies (Colomb \& Novy, 2018). A number of studies (Giaccardi \& Fischer, 2008; Sailer, 2011; Fischer, 2013) observe that "social creativity" (Montuouri \& Purser, 1997; Long \& Pang, 2015; Petrović-Šteger, 2018; Vodopivec, 2018) is an often-overlooked component of studies on the development of creative activities and that social creativity is often exploited to enhance the area's cultural attractiveness and market value. In so doing, social and cultural capital is used in the form of "marginal" or "bridging gentrificators" (Smith, 1996: 105) that serve the current needs of the area's development strategies without considering the area's long-term development.

The short-term nature of creative urban policies is frequently based on development perspectives that particularly relate to a product or result, overshadowing the significance of what Briskman (1980: 98) calls the "appropriateness, the internal connection' which exists between these products and the background against which they emerge" [sic]" (also see Poljak-Istenič, 2015: 34). By focusing on the final product, the process through which this product came about is placed in the secondary plan. Meusburger (2009) and Wierenga and van Bruggen (1998) nicely illustrate this lack of context in analyses of creative activities by analysing creativity in terms of the time component. Here, creativity as a "trait or input variable" is separated from creativity as a "process" and from a "variable as an achievement or output" (Wierenga \& van Bruggen, 1998: 84). The psychologists True (1966) and Klausmeier (1961) similarly distinguish "creative ability" from "creative capacity". Both categories rely on the time dimension, in which ability refers to the power to perform an action now, and performance refers to what could be done in the long run through maturation (gaining experience or cumulative effects), education, and interaction between components in the system.

This article therefore focuses on "creative capacity" (Lazaretti, 2012: 2), whereby in the long run individual urban areas act as "informal, collective open spaces that can absorb and recombine art and culture, leading to innovation and regeneration" (Lazaretti, 2012). To understand the soft (social) aspects of creative capacity, it is important to consider the function of social networks found in areas subject to urban renewal. Social networks play an important role in the formation and maintenance of spatial communities and are a key dimension of social capital (Bourdieu, 1986; Putnam, 1995, 2000; Filipović, 2007), which is formed based on "social networks, the norms of reciprocity, trust and positive consequences that this capital has for the individual and the social system" (Iglič, 2001: 186). In this context, social networks are defined as a process of persistent dynamic physical and social interaction within the framework of a specific space of interest (Shaw et al., 2016; Boessen et al., 2018). Social networks are especially important for the functioning of creative communities and creative ecosystems because they are based on intensive communication, mutual exchange, and the enrichment of information among users. In a creative ecosystem, social networks are a very valuable form of social capital without which other forms of capital have difficulty developing or are regarded as significantly less important. This is evident from a series of studies (Gottlieb, 1994; Landry \& Bianchini, 1995; Scott, 2000; Florida, 2002, 2005) in which the presence of relevant social networks is identified as a factor more important for the development of creative industries than other factors such as financial resources, technical infrastructure, or physical characteristics of the premises. With respect to highly creative individuals, material supply is an important element in creating favourable conditions for the development of creative industries, but it is not 
necessarily the decisive factor for "creative clustering" (Scott, 2000; Bell \& Jayne, 2001; Perrons, 2004), best represented in the growth and generational development of socioeconomic activities on site. This means that other elements in the area are also extremely important given that only a combination of favourable conditions that allow individual social and scientific development can provide good foundations for the long-term operation of creative economies.

The right conditions for the development of creative industries are in fact made up of several seemingly less important factors, among which social networks are the most often overlooked factor, one that importantly contributes to the appropriate "climate" or milieu for creative companies and creative individuals (Kozina \& Clifton, 2019; Poljak-Istenič, 2019). A series of attempts to develop creative areas based on physical renewal, and that to a smaller extent incorporated aspects of social networks, have proven problematic and less successful (Chase \& Crawford, 1999; Harvey, 2000; Nyseth, 2012). Social networks are an integral and sensitive part of any creative ecosystem, responding to certain spatial changes and translating them to the community level. They act as a refined network of sensors in the field that quickly detect the slightest changes in the organization and operation of specific spaces. These processes can be observed in several projects of redeveloping former urban areas where rapid, sudden changes are underway, changing everyday life patterns, services, and the structure of social groups in entire city districts, which is subsequently reflected in how the entire city functions. This analysis of the tobacco factory area in Ljubljana offers a practical example of the great importance that social networks hold for the operation of the creative ecosystem and identifies problematic aspects that emerged during the area's restructuring.

\section{Analysis of restructuring the tobacco factory area and the creative ecosystem}

\subsection{Description of the location and methodology}

The oldest part of the former tobacco factory complex in Ljubljana was built between 1871 and 1890 and is located between the railway line from Ljubljana to Trieste, the main arteries of Tivolska cesta (Tivoli Street) and Tržaska cesta (Trieste Street), and the side route of Oražnova ulica (Oražen Street). The area started to be developed at the end of 1870 , when the Ljubljana Municipal Council ceded the area for the industrial development of the tobacco industry without any payment (Tobačna Ljubljana, 2019). After decades of mixed industrial development, in 1991 the first key changes were made to

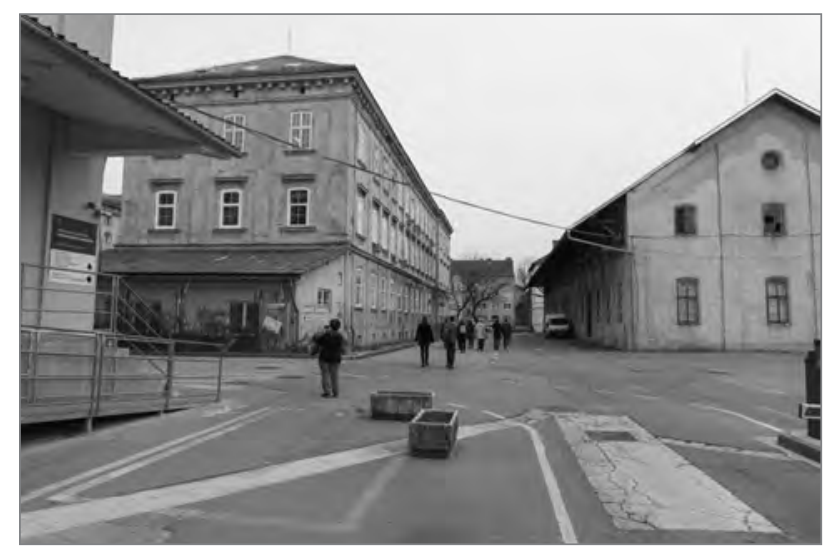

Figure 1: Former tobacco factory area, 2018 (photo: Urban Jeriha).

the ownership structure of the factory complex, leading to the gradual ending of tobacco production. The area's gradual privatization (by Reemtsma Cigarettenfabriken $\mathrm{GmbH}$, and SEITA, Société nationale d'exploitation industrielle des tabacs et allumettes) began in 1991 and continued with the majority entry of Imperial Tobacco in 2002. This was followed by the gradual halting of production activities at the company Tobačna Ljubljana, which completely stopped in 2004. As the production was closing down, discussions on the future use of the premises started. The premises were first used for several different activities, including the Tobacco Museum, a gallery, the Poligon Creative Centre, the Hekovnik Institute, design and architectural studios, a number of non-governmental organizations, start-ups and art institutions such as the Cirkulacija 2 Institute, various administrative services such as the Ljubljana Administrative Unit, and a multitude of other institutions, societies, and various companies related to creative activities (Figure 1).

The Creative Cities survey (Inštitut za politike prostora, 2011; Inštitut za ekonomska raziskovanja, 2012) found that in terms of the number of small creative companies (SMEs) and their heterogeneity this area is among the most dynamic areas in the country (Žaucer et al., 2012). According to data collected from the databases of the standard classification of activities (SURS, 2011), the tobacco factory area included over four hundred small enterprises with an average of two to three employees. In 2019, the entire tobacco factory area was sold off to a private investor, which changed the operating conditions for most tenants of the premises. It is evident from interviews with former users that significantly more difficult conditions for renting premises were introduced in 2019. The increase in rent suddenly proposed or requested by the new owner triggered a wave of users relocating from the tobacco factory area. This raises several questions about the function of the former users, their role, and the impact on the performance of Ljubljana's wider creative ecosystem. 
These issues are addressed by analysing the social networks in the tobacco factory area. From this point of view, the analysis provides a key tool for identifying the links between important actors and the use of spaces. This shows the importance of recognizing and connecting social interactions with the tobacco factory area, which should help "reflect, and enhance awareness of a context for agreements, conflicts, negotiations, misunderstandings, power relations and accountabilities" (Genz \& Lucas-Drogan, 2019: 2). The data set comprises semi-structured interviews with actors or premise users distributed into two phases of the longitudinal Urban Education Live study. The first phase took place between April and August 2018 and included thirty-one interviews with various stakeholder groups, and the second phase was between January and April 2020, when an additional thirty interviews were obtained (making sixty-one interviews altogether). The interviews were conducted based on a random sample of individuals that work within specific creative activities and act as users of the premises at the tobacco factory site. Stakeholder groups were weighted according to the principle of equal geographical distribution across the area (to reflect the different buildings in the tobacco factory area). A wide range of stakeholder groups was included in the analysis, from employees in creative businesses, public institutions, and non-governmental organizations to various institutes. Except for a few individuals, the tobacco factory area has no residents and is therefore primarily a mixed business/ craft/cultural area. The largest group of interviewees was thus employed in creative businesses, which are also key stakeholders in the tobacco factory area. The interviews were structured to permit analysis of certain elements of social networks in relation to the premises in the tobacco factory area. It is precisely because of this combination of socio-spatial analysis that the research needed to be supported by methods other than interviews. To support the interviews, a mix of different qualitative methods (participant observation, field observation, cognitive mapping, etc.) was therefore used, the combination of which was expected to provide a credible outline of the connections between the spaces and their meanings for the various actors.

\subsection{Analysis of changes in the operation of social networks in the tobacco factory area}

The analysis of the social networks is shown based on the time component - that is, by taking into account the influences on social networks in various time periods in the tobacco factory area. Insight into different time points is provided by longitudinal research that shows the multifaceted transformations that the social networks have gone through in individual phases. The analysis used data from sets of open-ended questions in semi-structured interviews, which were qualitatively analysed using basic text analysis. Pragmatic text analysis (Verschueren, 1995) was used, whereby dimensions of social networks were analysed following a review of the text and classification of the answers by individual categories. From the analysis of the Urban Education Live research data, it was possible to extrapolate several characteristics of the social networks of the creative ecosystem, which can be transferred to the broader context of the entire creative system of Ljubljana and the wider region by considering specific differences (based on the context, stakeholder structure, and geographical distribution). In other words, in the case of the tobacco factory area, selected characteristics of the connections between the social networks, along with the development of the social capital and operation of creative ecosystems, are presented, which are key elements (building blocks) of creative activities in Slovenia's broader area. The mode of operation and important institutional actors' consideration of these characteristics and elements affects either the short- or long-term creative capabilities of a city, region, or country. As part of the Urban Education Live survey, characteristics and changes between 2017 and 2020 in the operation of creative social networks in the tobacco factory area were identified. These are discussed below.

\subsubsection{Clustering creative activities through formal and informal networks}

The interviewees in the tobacco factory area generally possess quite diverse social networks. Further analysis showed that formal networks, defined as working, project, and contractual connections (a client-contractor relationship), have a significant impact on the development of creative activities and also depend strongly on informal networks based on friendly ties as manifested in socializing, spending free time during breaks, lunches, walks, drinking coffee, and so on. The interviewees were not asked about all forms of social contact, only about the most common, core contacts with which they establish their most frequent connections, which in practice means that a contact is established several times a week. On average, each interviewee listed five core contacts or persons at the informal level and two contacts at the formal level. Of these, on average one contact was a member of both formal and informal networks, being at the same time a friend, colleague, and business partner.

The complementarity between formal (work) and informal (friendly) connections is evident in the interviews, especially when considering the time component, which indicates the gradual transition of individual informal contacts into formal contacts, and vice versa. This is therefore a fluid or flexible form of connection between actors, business entities, and users that have a common location or spatial network that uses specific spaces. The interviews showed that most contacts were gradually formed through the use of various micro-locations in the tobacco factory area (open public areas, corridors, balco- 


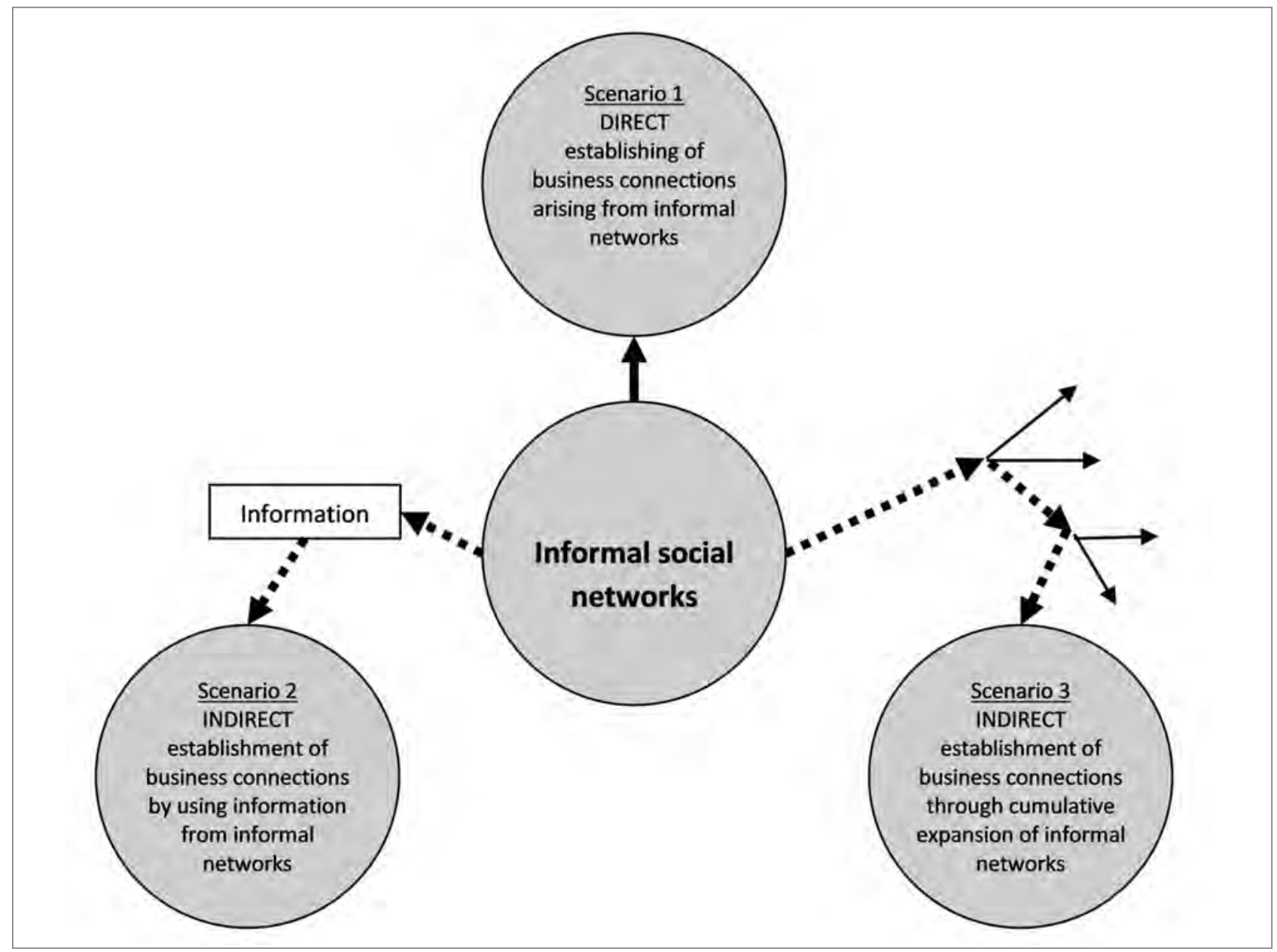

Figure 2: Presentation of clustering scenarios of creative activities based on informal networks (illustration: Matjaž Uršič).

nies, bars, restaurants, etc.), with the exchange of contacts and information. In particular, the increased number of informal contacts is noteworthy, which is understandable given that formal contacts were only considered those occurring outside the interviewee's direct working environment. Therefore, only connections with other companies or employees in the tobacco factory area beyond the interviewee's workspace were considered formal contacts. Both types of contacts indicate a much diverse business and creative ecosystem in which companies and individuals occasionally connect and collaborate, whereas clustering of companies occurs on the basis of the constant intertwining of formal and informal contacts.

The interviews showed the importance of informal contacts in the context of clustering creative activities. Informal contacts play an extremely valuable role and are basic communication channels that strengthen and establish interpersonal relationships and, due to the higher level of trust between creative individuals, also allow greater exchange of tacit information regarding the creative ecosystem's functioning. These are forms of indirect influence on the creation of a creative ecosystem, which, unlike direct influences, can remain excluded or unnoticed in analysis of the business environment (Figure 2). In other words, although informal networks may not result in direct business connections, the interviews show that they transmit information that either facilitates the indirect establishment of economic transactions or allows the gradual cumulative spread (the "snowball" principle) of informal contacts that also indirectly lead to the gradual expansion of business networks within the creative ecosystem of the tobacco factory area.

\subsubsection{The time component's influence on the number and range of connections in the social networks of the tobacco factory area}

Similar to other analyses of social networks (Filipović, 2007; Gibbons et al., 2018; Ye \& Liu, 2018), the data in the Urban Education Live survey indicate the extremely important role of the time length variable, or process duration. In this respect, the duration of certain processes related to individual locations (social nodes) determined how numerous and diversified an individual's networks are. The data show that the number of 


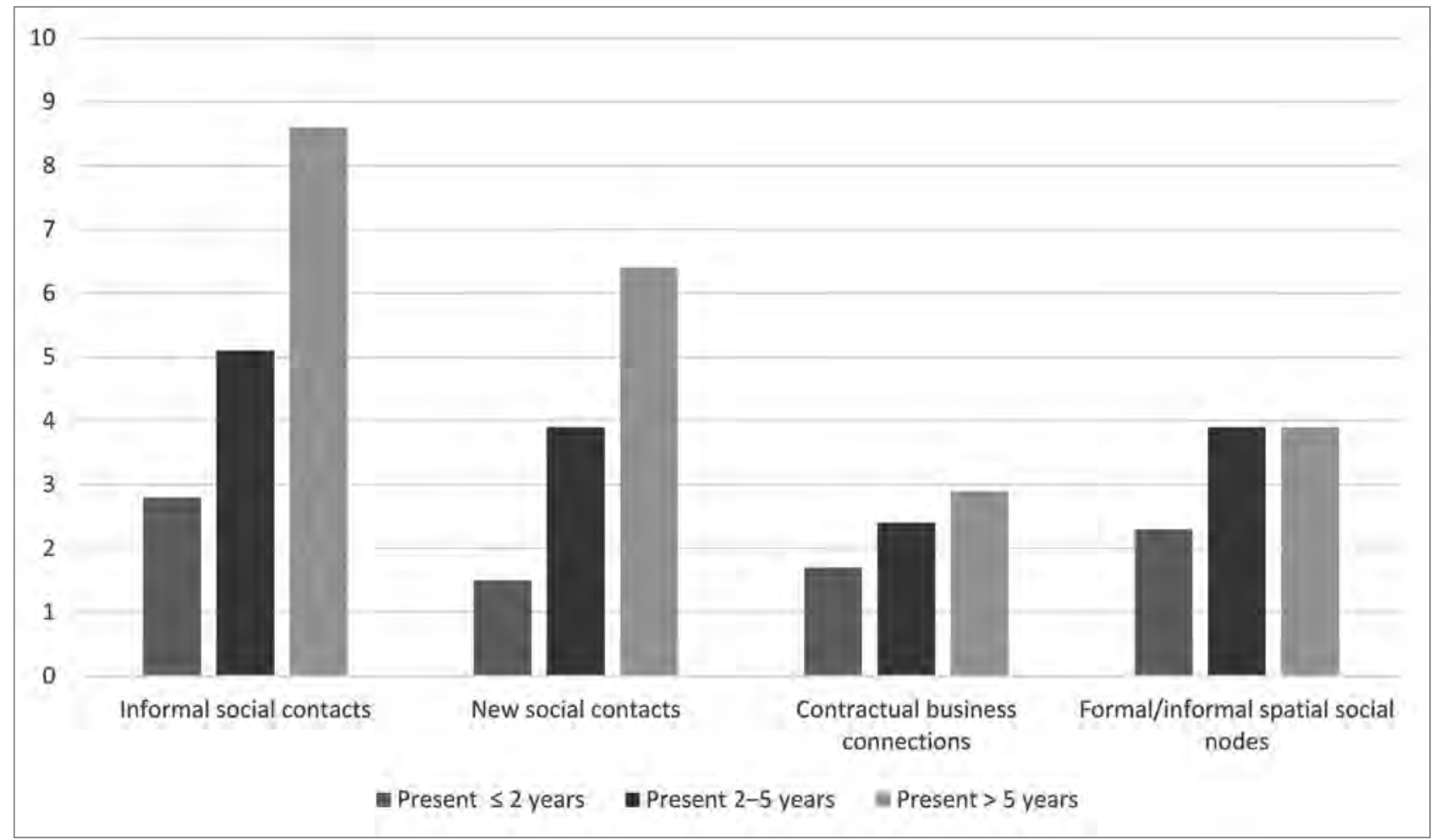

Figure 3: Increasing number and spatial diversification of various forms of social networks by number of years present in the tobacco factory area (source: Urban Education Live, 2019, 2020).

years spent by interviewees in the tobacco factory area strongly influences the intensity or depth of their social networks. A higher number of years in the area thus also corresponds to greater numerical and spatial diversification of an individual's informal and formal networks in the tobacco factory area (Figure 3).

Exponentially, as more years were spent in the tobacco factory area, a larger number of spaces were formed in the interviewees' "mental maps" (Lynch, 1990), including social nodes for formal and informal socializing in the tobacco factory area (the most popular social nodes were restaurants, bars, and entrances in front of the main buildings). Given the importance of social networks for creative clustering, the research showed that the number of years of individual presence in the tobacco factory area also influenced the acquisition of new formal social contacts in that area, which were realized as various forms of contractual business collaboration. As the years present in the area increased, the number of contractual business connections also increased. On average, the interviewees gained 3.5 new contacts while active in the tobacco factory area. When asked about the strength of these contacts, they stated that approximately three core contacts from the list of key people mentioned had assisted or helped them with various events, which further testifies to the strength of the social networks formed among the tobacco factory users.

\subsubsection{Reduction in the volume of social networks and the impact on social capital}

The analysis of formal and informal contacts in relation to a time variable showed how social capital has gradually accumulated in the tobacco factory area and is materialized in social networks in the form of various creative activities, companies, and business contacts. It should be emphasized that the social capital that has accumulated at this location is intertwined with the locality or local structure at the physical, cultural, and social levels. It may be described as a principle of the "social production of space" (Lefebvre, 1991, 299-346), where space as a physical category becomes inseparable from the social structure of space. Lefebvre draws attention to the great importance of the temporal component of space production because this means that over time, based on specific uses (spatial practices, presentation of space, spaces of representation, and collective experience), a new space emerges that eludes simple definitions of a physical good with an aesthetic value. If the production of a space is based solely on the physical change made to that space and excludes other forms of (social) values that have arisen in the area, the spatial development process becomes simplified, which leads to a reduction of social capital and social networks. This was seen in the context of restructuring the tobacco factory area when comparing the interview data for the period before (in 2018) and after the sale of the area (in 2020), which then led to the closure of the 


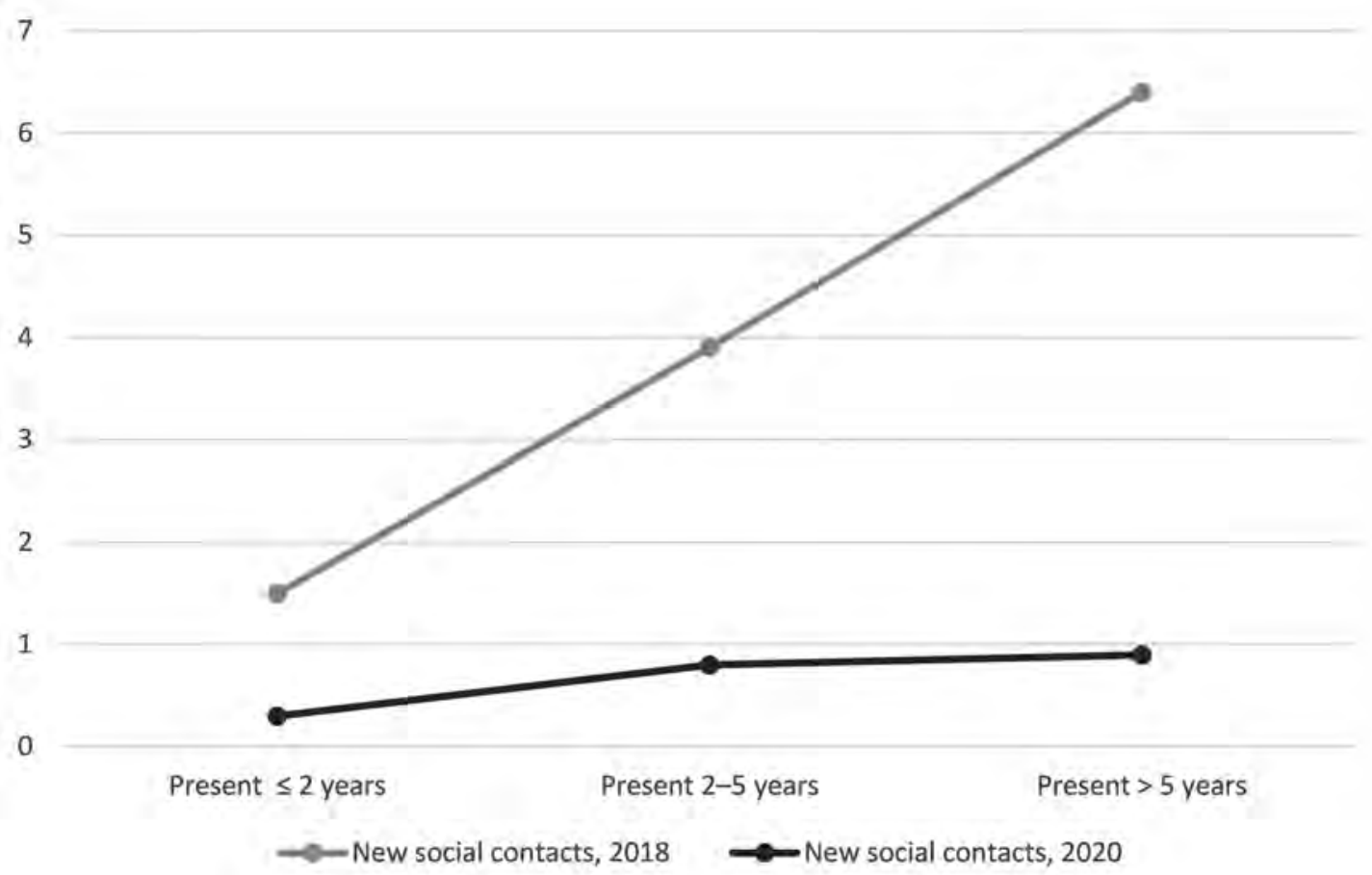

Figure 4: Comparison of growth in new social contacts between 2018 and 2020 (source: Urban Education Live, 2019, 2020).

most creative activities. After the sale of the majority of the area, only the building located at Tržaška 2 remained available for creative activities, which has led to a sharp decrease in the volume of all analysed dimensions of formal and informal networks and business (contractual) connections. For example, in the comparative period from 2018 to 2020, the index of newly established social connections dropped from an average of four connections to about one new connection (Figure 4).

The data thus show that the closure of most social nodes in the area has drastically limited the expansion of the social networks. The prevention of any further development of social networks in the area, which is subject to a full functional, service, and activity restructuring, may be described as a logical consequence of the spatial transformation process, although attention must also be drawn to the general shrinkage of social networks resulting from the forced relocation of certain creative actors at the tobacco factory site to other sites around the city. Namely, even though the creative actors that remained or moved away from the tobacco factory area stated they had established some new contacts but on a smaller scale than in previous years, they also explained there had been a reduction in the volume and frequency of their daily connections in the social networks of formal and informal contacts after the area's restructuring. The current and former groups of tobacco factory users agreed that the area's restructuring had affected the frequency of meeting, cooperating, and socializing with other tobacco factory users (Figure 5).
The longitudinal analysis made it possible to compare the modified social networks of current users of the tobacco factory area and former ones, who had been forced to move away from the location after the change in ownership. Of the thirty people interviewed in 2020, about one-third were part of this group. This group of interviewees was particularly interesting due to the possibility of comparison with 2018 because the marked reduction of their social networks tied to the tobacco factory area indicates the inability or difficulty of maintaining creative social networks during the spontaneous development of creative activities. Although social networks essentially operate based on intangible connections and are not directly related to physical parameters and do not depend on visible bases, the data show that the attempt to separate them (through relocation or eviction) from the local context or milieu has strongly influenced the scope and functionality of the creative networks. This emphasizes the importance of the social production of space, where complex communication and production relations between creative actors are formed following a multi-year process. Obstruction of this process leads to a reduced volume of the creative ecosystem, meaning that additional costs for the city can be identified in the time that has been lost and that will be needed to redevelop similar creative networks in other locations in the city. One can only guess how many economic resources and years it will take to establish similar new hubs and restore social networks in the creative ecosystem of small businesses, which already hold a less privileged position due to the harsh market conditions that demand short-term maximization of capital. 


\section{Current tobacco factory users}

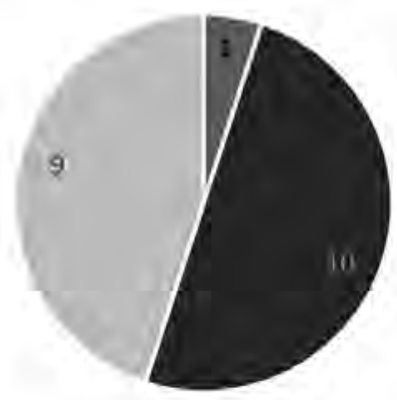

- More contacts

\section{Moved (former) Tobačna users}

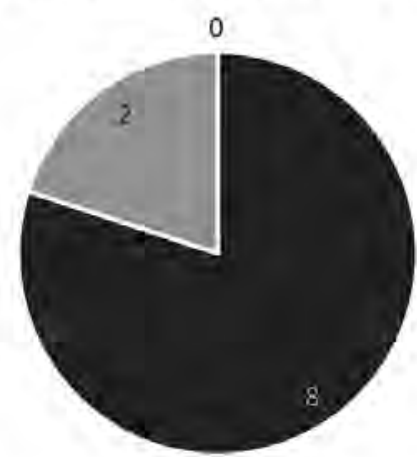

- More contacts

- Same number of contacts

Figure 5: Do you socialize, meet, or cooperate with other tobacco factory users after the sale of the area? Comparison of existing and relocated creative actors in the tobacco factory area, 2020 ( $n=30$; source: Urban Education Live, 2019, 2020).

\section{Discussion}

The example of the tobacco factory area shows the specific conditions in which creative activities operate in Slovenia. This context may be described as the spontaneous development of creative activities in a setting of free market conditions. Under these conditions, the priority factor in establishing creative nodes or milieus becomes the proximity of the largest market or the size of the aggregate population and the geographical location of the infrastructural, historical, and administrative centres of the region (Kozina 2010). From this viewpoint, the distribution of creative activities in Ljubljana and its urban region approaches the idea of "central places" (Christaller, 1966; Logan \& Molotch, 1987; Cigale, 2002; Burger \& Meijers, 2012), as characterized by the accumulation of resources and potential only in locations that provide the greatest economic yield and have an adequate concentration of people.

Building on these characteristics, the tobacco factory creative ecosystem was gradually formed, where conditions in a certain period were favourable to these processes (relative proximity to the city centre, access to relatively affordable rental spaces, rapid accumulation of similar creative activities and actors, etc.). The problem of such a spontaneous development of creative milieus, where actors, small companies, and soft (social) factors converge, lies in the possibility of sudden changes to its operating conditions, which often leads to the rapid disintegration of such creative cores. In the event of sudden changes in market conditions (due to political, economic, or historical events), producing changes in the system of central locations, there may be a complete breakdown of the creative ecosystem in these locations. In such a constellation, creative SMEs may be seen as weaker actors that, despite playing an important role in maintaining social capital in creative areas, are simply pushed out of locations. In this hierarchical arrangement, due to the displacement of weaker forms of creative actors, the homogenization of activities, and development, the concentration of stronger types of creative actors gradually occurs, in turn leading to the uneven spatial distribution of creative activities. This all works to diminish the functional heterogeneity of creative ecosystems because the most successful are those industries, companies, and actors that have quick access to a large market and the surrounding area, from which they draw the necessary human resources. This "selection of the fittest", which leads to profiling creative actors in terms of their ability to respond quickly to current economic conditions, may be described as "the entropic dimension of the socioeconomic system" (Kirn 2008). In an entropic socioeconomic system, the energies or actors and companies involved in the development of creative activities accumulate in certain locations, yet there is a danger that after a certain time period - due to an unsteady, poor economic base, insufficient environmental incentives, or inability to upgrade in the long term because of limited access to basic (bottom-up) spatial, social, and human resources - these creative accumulations start to fade, become dispersed, or even cease to exist.

\section{Conclusion}

The introduction to this article presented a hypothesis on the inability of local authorities and state institutional actors to perceive the importance of soft (social) factors for the functioning of creative ecosystems. After analysing various research data, that assumption was confirmed and it was shown how 
important soft factors are for the design and maintenance of the creative ecosystem. The inseparability of the soft (social) elements from creative production itself was proven based on an analysis of connections between formal and informal social networks. In particular, the informal networks played an important role as a communication platform for establishing an appropriate creative milieu and for clustering creative activities. The data also indicate the extraordinary importance of the time component for the development of creative activities. Divisions between the short- and long-term accumulation of social connections or contacts translate into the performance of the creative ecosystem. Last but not least, maintaining the heterogeneity of actors in creative activities is necessary for the long-term successful operation of a creative ecosystem because creative social networks cannot be moved from one location to another without harmful collateral effects. These are seen in the loss of accumulated social capital (creative networks), as well as in the time and economic resources needed to gradually establish similar creative milieus.

The shortcomings of short-sighted policies of spontaneous market development for urban creative activities are reflected in alternating, repeating cycles between extinction and accumulation attempts of creative social networks, which in the long term may produce a gradual decline in intangible forms of social capital. This raises important questions about the extent to which urban policies should be involved in planning creative milieus, given that it is difficult to control the effects of the formal spatial planning system on the intangible characteristics of spaces. Every urban policy that tries to top-down direct or plan creativity probably inevitably faces conflicts. Creating creative ecosystems involves complex, partially unmanageable variables and factors that make precise urban planning unpredictable and inefficient. As a result, in designing creative policies attention must be shifted to ensuring an increase in the ability to measure, analyse, or detect elements from the bottom up, which so far have been unjustifiably underestimated in the analysis of creative activities (Colomb \& Novy, 2018). In this context, the redevelopment of the tobacco factory area is an exemplary case of an inappropriate approach while measuring certain "intangible values" of creative areas. Similar examples of a questionable, insufficient analysis of the importance of social networks for Ljubljana's socioeconomic system can be given by referring to other cases not specifically discussed in this article (e.g., the former Rog Factory or the Metelkova area). Olsson (1999) and Bianchini (1999), for example, mention that there is no single method for measuring intangible values, which causes extreme conflicts and tensions and introduces major problems into spatial planning. At the political level, there are large discrepancies between individual disciplines with regard to the need to measure such elements. The problem of creative urban policies in Slovenia is therefore not the inability to plan such activities, but the inability to systematically detect and allow the operation of elements that are vital for the maintenance, preservation, and development of such activities. Scott (2014: 569) notes here that, before any change is made to creative urban policy, authorities must obtain a detailed socio-historical insight and understanding of the specific features of local urban development prior to engaging in "the shaping of local patterns of ingenuity and imagination". Institutional actors' avoidance of the much-needed prior analysis of local conditions creates an "unjustified dose of simplistic thinking" (Scott, 2014: 574) and triggers scepticism, which often leads to the introduction of regressive urban policies.

In the Slovenian post-transition period, the "productionist approach" (Hall \& Robertson, 2001: 19) dominates urban creativity development. Use of this concept reflects the concerns held by authorities regarding economic production and the capitalization of creativity. This is also seen in documents that seek to include the tobacco factory area in such development schemes (see, e.g., Mestna občina Ljubljana, 2012, 2016, 2020). However, this approach does not adequately assess the long-term role and impact of creativity on the city in the current context of postmodern, globalized environments. From this perspective, future approaches to creative urban regeneration will need to develop mechanisms able to detect changes in the subtle structure of the creative ecosystem and to combine the cultural, social, and economic value of creativity into a single whole. This article has drawn attention to and helped explain at least some of the neglected aspects of creativity to highlight their importance and role in the creative ecosystem. In the long run, Ljubljana may be considerably affected by sometimes less noticeable micro-changes at the local level. This should lead to the development of new models of evaluation of valuable sociocultural elements, places, and spaces in the city. Such a process cannot be carried out in a short time because it requires breaking away from the current spatial planning paradigm. This production paradigm in spatial planning consists of a set of ideas, thought models, and, above all, a system of values embedded in the very organization and functioning of institutions, communities, and everyday users of the city, region, and country. Moving away from the current paradigm is a painstaking and time-consuming process. The development of Ljubljana's long-term creative capacities is thus based on a qualitative leap, which may be seen as a new socio-spatial paradigm or "paradigmatic shift" (Kuhn, 1970: 85) that in a holistic mode encompasses systems of economic, urban, and especially social development.

Matjaž Uršič, Centre for Spatial Sociology, Faculty of Social Sciences, University of Ljubljana, Ljubljana, Slovenia

E-mail: matjaz.ursic@fdv.uni-lj.si 


\section{Acknowledgements}

The article was created with the help of the Urban Education Live (UEL) project. The project was co-financed by the Slovenian Research Agency (ARRS, project title: UEL, Urbano izobraževanje v živo; code: $\mathrm{H} 5-8286)$ and the $\mathrm{EU}$ as part of the joint programme initiative Urban Europe, ERA-NET Cofund Smart Urban Futures (ENSUF), project no. 693443.

\section{References}

Bell, D. \& Jayne, M. (2004) City of quarters: Urban villages in the contemporary city. London, Ashgate.

Bianchini, F. (1999) Cultural planning for urban sustainability. In: Nystrom, L. (ed.) City and culture: Cultural processes and urban sustainability, pp. 34-51. Kalmar, Sweden, The Swedish Urban Environment Council.

Boessen, A., Hipp, J. R., Butts, C. T., Nagle, N. N. \& Smith, E. J. (2018) The built environment, spatial scale, and social networks: Do land uses matter for personal network structure? Environment and Planning B: Urban Analytics and City Science, 45(3), pp. 400-416. DOI: 10.1177/2399808317690158

Bole, D. (2008) Cultural industry as a result of new city tertiarization. Acta Geographica Slovenica, 48(2), pp. 255-276. DOI: 10.3986/AGS48202

Bourdieu, P. (1986) The forms of capital. In: Richardson, J. G. (ed.) Handbook of theory and research for the sociology of education, pp. 241-258. New York, Greenwood Press.

Briskman, L. (1980) Creative product and creative process in science and art. Inquiry, 23(1), pp. 83-106. DOI: 10.1080/00201748008601892

Burger, M. \& Meijers, E. (2012) Form follows function? Linking morphological and functional polycentricity. Urban Studies, 49(5), pp. 1127-1149. DOI: $10.1177 / 0042098011407095$

Chase, J., Crawford, M. \& Kalinski, J. (1999) Everyday urbanism. New York, Monacelli Press.

Christaller, W. (1966) Central places in southern Germany. Englewood Cliffs, NJ, Prentice-Hall.

Cigale, D. (2002) Centralna naselja v Sloveniji in njihova vplivna območja v letu 1999. Geografski vestnik, 74(1), pp. 43-56.

Clarke, J., Bainton, D., Lendvai, N. \& Stubbs, P. (2015) Making policy move: Towards a politics of translation and assemblage. Bristol, Policy Press. DOI: 10.1332/policypress/9781447313366.001.0001

Cohendet, P., Grandadam, D. \& Simon, L. (2010) The anatomy of the creative city. Industry \& Innovation, 17(1), pp. 91-111. DOI: $10.1080 / 13662710903573869$

Colomb, C. \& Novy, J. (2018) Protest and resistance in the tourist city. Contemporary geographies of leisure, tourism and mobility. New York, Routledge.

European Commission (2010) Zelena knjiga - Izkoriščanje potenciala kulturnih in ustvarjalnih industrij (The green book on cultural and creative industries). . . Available at: https://eur-lex.europa.eu/legal-content/SL/ ALL/?uri=CELEX\%3A52010DC0183 (accessed 10 Dec. 2020).

Filipović, M. (2007) Prostorska determiniranost omrežij starejših in vloga sosedov v časovni perspektivi. Teorija in praksa, 44(1-2), pp. 298-316.

Fischer, G. (2013) Learning, social creativity, and cultures of participation. In: Sannino, A. (ed.) Learning and collective creativity: Activity-theoretical and sociocultural studies, pp. 198-215. London, Routledge. DOI: 10.4324/9780203077351
Florida, R. L. (2002) The rise of the creative class: And how it's transforming work, leisure, community and everyday life. North Melbourne, Australia, Pluto Press.

Florida, R. L. (2005) Cities and the creative class. London, Routledge. DOI: $10.4324 / 9780203997673$

Florida, R., Gates, G., Knudsen, B. \& Stolarick, K. (2006) The university and the creative economy. Creative class group. Available at: http://creativeclassgroup.com/rfcgdb/articles/University\%20For\%20City\%20and\%20Community\%204.pdf (accessed 10 Dec. 2020).

Genz, C. \& Lucas-Drogan, D. (2017) Decoding mapping as practice: An interdisciplinary approach in architecture and urban anthropology. Urban Transcripts Journal, 1(4), pp. 1-10 Available at: http://journal.urbantranscripts.org/article/decoding-mapping-practice-interdisciplinary-approach-architecture-urban-anthropology-carolin-genz-diana-lucas-drogan/ (accessed 10 Dec. 2020)

Giaccardi, E. \& Fischer, G. (2008) Creativity and evolution: A metadesign perspective. Digital Creativity, 19(1), pp. 19-32. DOI: $10.1080 / 14626260701847456$

Gibbons, J., Nara, A. \& Appleyard, B. (2018) Exploring the imprint of social media networks on neighborhood community through the lens of gentrification. Environment and Planning B: Urban Analytics and City Science, 45(3), pp. 470-488. DOI: 10.1177/2399808317728289

Gottlieb, P. D. (1994) Amenities as an economic development tool: Is there enough evidence? Economic Development Quarterly, 8(3), pp. 270-285. DOI: $10.1177 / 089124249400800304$

Hall, T. \& Robertson, I. (2001) Public art and urban regeneration: Advocacy, claims and critical debates. Landscape Research, 26(1), pp. 5-26. DOI: 10.1080/01426390120024457

Harvey, D. (2000) Spaces of hope. Berkeley, University of California Press. Hesmondhalgh. D. (2002) The cultural industries. London, Sage.

Howkins, J. (2001) The creative economy: How people make money from ideas. London, Allen Lane.

Iglič, H. (2001) Socialni kapital, socialna omrežja in politično vedenje: empirična študija. Družboslovne razprave, 17(37/38), pp. 167-190.

Inštitut za ekonomska raziskovanja (2012) Creative industries in Ljubljana urban region. Ljubljana.

Inštitut za politike prostora (2011) Potentials of creative urban regeneration spatial distribution of creative industries in Ljubljana Urban Region. Ljubljana, ERDF, RRA-LUR.

Internet 1: https://www.canada.ca/en/canadian-heritage/campaigns/creative-canada/framework.html (accessed 10 Dec. 2020).

Internet 2: http://www.culture.gov.uk/index.aspx (accessed 10 Dec. 2020).

Internet 3: https://ec.europa.eu/info/research-and-innovation/strategy/ goals-research-and-innovation-policy/innovation-union_en (accessed 10 Dec. 2020).

Jeffcutt, P. (2004) Knowledge relationships and transactions in a cultural economy: Analysing the creative industries ecosystem. Media International Australia Incorporating Culture and Policy, 112(1), pp. 67-82. DOI: $10.1177 / 1329878 \times 0411200107$

Kirn, A. (2008) Entropične razsežnosti družbenega razvoja. Teorija in Praksa, 45(3-4), pp. 249-284.

Klausmeier, H. J. (1961) Learning and human abilities: Educational psychology. 3rd ed. New York, Harper \& Row.

Kozina, J. (2010) Transport accessibility to regional centres in Slovenia. Acta geographica Slovenica, 50(2), pp. 231-251. DOI: 10.3986/AGS50203 
Kozina, J. \& Bole, D. (2018) The impact of territorial policies on the distribution of the creative economy: Tracking spatial patterns of innovation in Slovenia. Hungarian Geographical Bulletin, 67(3), pp. 259-273. DOI: 10.15201/hungeobull.67.3.4

Kozina, J. \& Clifton, N. (2019) City-region or urban-rural framework. Acta geographica Slovenica, 59(1), pp. 141-157. DOI: 10.3986/AGS.5137

Kuhn, T. S. (1970) The structure of scientific revolutions. Chicago, University of Chicago Press.

Landry, C. \& Bianchini, F. (1995) The creative city. London, Demos.

Lazzeretti, L. (2012) The remarkable resilience of Florence, city of art. Available at: https://www.regionalstudies.org/wp-content/uploads/2018/07/lazzeretti. pdf (accessed 10 Dec. 2020).

Lefebvre, H. (1991) The production of space. Malden, MA, Blackwell.

Logan, J. R. \& Molotch, H. L. (1987) Urban fortunes: The political economy of place. Berkeley, University of California Press.

Long, H. \& Pang, W. (2015) Rater effects in creativity assessment: A mixed methods investigation. Thinking Skills and Creativity, 15, pp. 13-25. DOI: 10.1016/j.tsc.2014.10.004

Lynch, K. \& City Sense, City Design (1990) Writings and projects of Kevin Lynch. Cambridge MA, MIT Press.

Martin-Brelot, H., Grossetti, M., Eckert, D., Gritsai, O. \& Kovács, Z. (2010) The spatial mobility of the "creative class": A European perspective. International Journal of Urban and Regional Research, 34(4), pp. 854-870. DOI: 10.1111/j.1468-2427.2010.00960.x

Mestna občina Ljubljana (2012) Strategija razvoja kulture v Mestni občini Ljubljana 2012-2015. Ljubljana.

Mestna občina Ljubljana (2016) Strategija razvoja kulture v Mestni občini Ljubljana 2016-2019. Ljubljana.

Mestna občina Ljubljana (2020) Strategija razvoja kulture v Mestni občini Ljubljana 2020-2023 z usmeritvami do leta 2027. Ljubljana.

Meusburger, P. (2009) Milieus of creativity: The role of places, environments, and spatial contexts. In: Meusburger P., Funke J., \& Wunder E. (eds.) Milieus of creativity, pp. 97-153. Dordrecht, Springer Netherlands. DOI: 10.1007/978-1-4020-9877-2_7

Ministry of Economy, Trade and Industry (2012) Cool Japan strategy. Modified version of the interim report submitted to the Cool Japan Advisory Council. Available at: https://www.meti.go.jp/english/policy/mono_info_service/ creative_industries/pdf/121016_01a.pdf (accessed 10 Dec. 2020).

Montouri, A. \& Purser, R. (1997) Social creativity: The challenge of complexity (Le dimensioni sociali della creatività). Pluriverso, 1(2), pp. 78-88.

Murphy, E. \& Redmond, D. (2008) Location factors of creative knowledge companies in Dublin Region: The managers' view. Amsterdam, University of Amsterdam

Musterd, S. \& Gritsai, O. (2013) The creative knowledge city in Europe: Structural conditions and urban policy strategies for competitive cities. European Urban and Regional Studies, 20(3), pp. 343-359. DOI: $10.1177 / 0969776412439199$

Nered, J. (2005) Geografski vidiki mreženja podjetij v Sloveniji. Geografski vestnik, 77(2), pp. 45-57.

Nyseth, T. (2012) Fluid planning: A meaningless concept or a rational response to uncertainty in urban planning? In: Burian J. (ed.) Advances in spatial planning, pp. 27-46. Shanghai, InTech. DOI: 10.5772/35098

Olsson, K. (1999) Cultural built heritage as a strategy. In: Nystrom, L. (ed.) City and culture: Cultural processes and urban sustainability, pp. 430-444. Kalmar, Sweden, The Swedish Urban Environment Council.
Peck, J. (2011) Geographies of policy: From transfer-diffusion to mobility-mutation. Progress in Human Geography, 35(6), pp. 773-797. DOI: $10.1177 / 0309132510394010$

Peck, J. \& Theodore, N. (2015) Fast policy: Experimental statecraft at the thresholds of neoliberalism. Minneapolis, University of Minnesota Press. DOI: 10.5749/minnesota/9780816677306.001.0001

Perrons, D. (2004) Globalization and social change: People and places in a divided world. London, Routledge. DOI: 10.4324/9780203646434

Petrović-Šteger, M. (2018) O "odprtem pogledu". Glasnik Slovenskega etnološkega društva, 58(3/4), pp. 7-24.

Poljak-Istenič, S. (2015) Kolo kot akter ustvarjalne urbane regeneracije. Glasnik Slovenskega etnološkega društva, 55(3/4), pp. 23-37.

Poljak-Istenič, S. (2017) Creativity: An introduction to popular concepts, topics, and discussions (Ustvarjalnost: uvod $\mathrm{v}$ razširjene koncepte, teme in razprave). Traditiones, 46(1-2), pp. 103-125.

DOI: 10.3986/Traditio2017460201

Poljak-Istenič, S. (2019) Participatory urbanism. Acta geographica Slovenica, 59(1), pp. 127-140. DOI: 10.3986/AGS.5142

Pratt, A. C. (2004) Creative clusters: Towards the governance of the creative industries production system? Media International Australia Incorporating Culture and Policy, 112(1), pp. 50-66. DOI: 10.1177/1329878X0411200106

Putnam, R. D. (1995) Tuning in, tuning out: The strange disappearance of social capital in America. PS: Political Science and Politics, 28(4), pp. 664-683. DOI: $10.2307 / 420517$

Putnam, R. D. (2000) Bowling alone: The collapse and revival of American community. New York, Simon \& Schuster. DOI: 10.1145/358916.361990

Ravbar, M. (2011) Creative social groups in Slovenia: Contribution to geographic studying of human resources. Acta geographica Slovenica, 51(2), pp. 293-318. DOI: 10.3986/AGS51204

Regionalna razvojna agencija ljubljanske urbane regije (2007) Regionalni razvojni program Ljubljanske urbane regije 2007-2013. Available at: https:// rralur.si/regija/razvojni-dokumenti/ (accessed 10 Dec. 2020).

Regionalna razvojna agencija ljubljanske urbane regije (2014) Regionalni razvojni program Ljubljanske urbane regije 2014-2020. Available at: https:// rralur.si/regija/razvojni-dokumenti/ (accessed 10 Dec. 2020).

Regionalna razvojna agencija ljubljanske urbane regije (2019) Regionalni razvojni program Ljubljanske urbane regije 2021-2027 (Osnutki). Available at https://rralur.si/regija/razvojni-dokumenti/ (accessed 10 Dec. 2020).

Rivas, M. (2011) From creative industries to the creative - Place refreshing the local development agenda in small and medium-sized towns. Available at: http://www2.cetiqt.senai.br/ead/redige/index.php/redige/article/ view/112/170 (accessed 10 Dec. 2020)

Sailer, K. (2011) Creativity as social and spatial process. Facilities, 29(1/2), pp. 6-18. DOI: 10.1108/02632771111101296

Scott, S. J. (2000) The cultural economy of cities: Essays on the geography of image-producing industries. London, Sage. DOI: 10.4135/9781446217481

Scott, A. J. (2014) Beyond the creative city: Cognitive-cultural capitalism and the new urbanism. Regional Studies, 48(4), pp. 565-578. DOI: $10.1080 / 00343404.2014 .891010$

Shaw, S.-L., Tsou, M.-H. \& Ye, X. (2016) Editorial: Human dynamics in the mobile and big data era. International Journal of Geographical Information Science, 30(9), pp 1687-1693. DOI: 10.1080/13658816.2016.1164317

Služba vlade Republike Slovenije za razvoj (2008) Priporočila 9. razvojne skupine za kreativne industrije za povečanje konkurenčnosti Slovenije. Ljubljana. 
Smith, N. (1996) The new urban frontier: Gentrification and the revanchist city. London, Routledge.

SURS (2011) SKD - Standardna klasifikacija dejavnosti. Available at: http:// www.ajpes.si/Registri/Drugo/SKD (accessed 10 Dec. 2020).

True, S. (1966) A study of the relation of general semantics and creativity. The Journal of Experimental Education, 34(3), pp. 34-40.

DOI: $10.1080 / 00220973.1966 .11010934$

Urban Education Live (2019) UEL - Skupnost Tobačna (Tobacco Factory Community): Final research report - Phase 2. Ljubljana, Faculty of Social Sciences, Centre for Spatial Sociology.

Urban Education Live (2020) UEL - Skupnost Tobačna (Tobacco Factory Community): Final research report - Phase 3. Ljubljana, Faculty of Social Sciences, Centre for Spatial Sociology.

Uršič, M. (2016) Characteristics of spatial distribution of creative industries in Ljubljana and the Ljubljana region. Acta Geographica Slovenica, 56(1), pp. 75-99. DOI: 10.3986/AGS.745

Uršič, M. \& Imai, H. (2020): Creativity in Tokyo: Revitalizing a mature city. Singapore, Palgrave Macmillan, Springer. DOI: 10.1007/978-981-15-6687-5

Verschueren, J. (1995) The pragmatic return to meaning: Notes on the dynamics of communication, degrees of salience, and communicative transparency. Journal of Linguistic Anthropology, 5(2), pp. 127-156. DOI: 10.1525/jlin.1995.5.2.127

Vodopivec, N. (2018) Vizije prihodnosti in družbene spremembe v Sloveniji. Glasnik Slovenskega etnološkega društva, 58(3/4), pp. 39-50.

Wierenga, B. \& van Bruggen, G. H. (1998) The dependent variable in research into the effects of creativity support systems: Quality and quantity of ideas. MIS Quarterly, 22(1), pp. 81-87. DOI: 10.2307/249679

Ye, X. \& Liu, X. (2018) Integrating social networks and spatial analyses of the built environment. Environment and Planning B: Urban Analytics and City Science, 45(3), pp. 395-399. DOI: 10.1177/2399808318772381

Žaucer, T., Peterlin, M., Uršič, M., Očkerl, P. \& Marn, T. (2012) Kreativna urbana regeneracija. Ljubljana, IPoP. 